\title{
Encouragement Of Entrepreneurship In Affluent Economies: The Case Of Kuwait
}

Adel Al-Wugayan, Kuwait University, Kuwait

Turki Alshimmiri, Kuwait University, Kuwait

\begin{abstract}
This paper investigates how Kuwait's young population (university students) reckons business incubation as an encouragement vehicle to promote small business creation at the time students finish their university schooling. Mainly, it attempts to measure how Kuwaiti university students view small business ventures. This might be very crucial as the main economic challenges in Kuwait now relate to the compelling need for economic diversification. The results mainly show a high willingness for both males and females to participate in small business creation.
\end{abstract}

Keywords: Dividend Policy, Survey, Emerging Market, Bird in the hand, Catering Hypothesis, Liquidity Constraints

\section{INTRODUCTION}

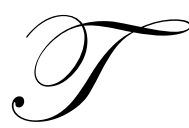

here recently has been a growing interest in entrepreneurship all over the world. Due to some economic difficulties in developing and developed countries, policy makers have recognized the importance and the instrumental role of the entrepreneurship in enhancing the economic prosperity and mitigating the problem of high unemployment rates. By having the highest capital-employment ratio, small businesses have been sought as an important vehicle that provides opportunities for young graduates to exhibit their entrepreneurial potential and become job creators rather than job seekers. Entrepreneurship could play a major role in economic growth and prosperity through their major role in job creation, savings and investments promotion, skills development, and innovation stimulation, hence, being a crucial engine for creating the wealth in economy.

According to recent figures published at the website of the World Bank, small businesses have created about $97 \%$ of the jobs in China, about $85 \%$ in USA, and about $87 \%$ in Japan. In light of such importance, policy makers in several industrialized countries have stressed the importance of supporting entrepreneurship via many ways. The most important of these are business incubators, innovation centers, technology transfer offices, and science parks. Also, among the most vital measures is calling academic institutions to develop a high-quality entrepreneurship education and training programs in order to create and support the entrepreneurial spirit among students. Some commentators have conjectured that incubating entrepreneurs during their beginning years in business is very efficient and necessary for the development of a strong base of high value-added ventures, which in turn boosts the economy. It is strongly believed that entrepreneurs might be born with promising traits, but these traits can be sharpened by training to become valuable skills qualifying someone to become full-fledged entrepreneur.

Although this paper touches upon the importance of a business incubator as a means to achieve a noble goal of pushing Kuwait university students to be involved in small business creation at the time they finish their university schooling, it is mainly intended to measure how Kuwaiti university students view small business ventures. This might be very crucial as the main economic challenges in Kuwait now relate to the compelling need for economic diversification. Young population (under 18 years) in Kuwait now is about 45\% (end of year 2008). There is a great dependency in Kuwait on expatriates who constitute about $90 \%$ of the labor force. This topic has never been touched upon in a country like Kuwait where students are members of somewhat relatively wealthy families. Kuwaiti students usually have a trouble-free alternative of a government-based employment that pays satisfactory compensation relative to that at the private sector. Even if they wish, Kuwaiti students can practice some form of a 
business even if they are governmentally employed, by exploiting a business license granted to one of the unemployed parents (usually the mother) or even lease a license and embark upon their ventures.

\section{MOTIVATION OF THE STUDY}

The nurturing of small businesses and entrepreneurial startups in Kuwait has received substantial attention in the last five years. After several failures of financial assistance programs directed toward new small-scale startups, the government now expects a more essential role of university education in fostering positive entrepreneurial attitudes among interested members of society. More specifically, entrepreneurial spirit can be encouraged among young university students so that local pressure on employment in government jobs can be condensed to avoid a situation where university graduates have to endure a job-searching waiting period that might exceed a year. This situation continue to create sharp social criticism in light of the fact that, in the past, most graduates waited less than one month, on average, to join the work force at a government post. Graduates of professional and applied schools, such as business and engineering, may possess some experience needed for founding, running, and/or owning small businesses. However, significant efforts are still needed to provide the appropriate infrastructure from government institutions and technical support entities. So far, only a few attempts and uncoordinated support have been provided for this segment of the economy. The outcome of the Kuwaiti small business initiative did not yield the desired outcome despite the generous financing offered. Social outcry in local media points to the need for more direct support to guide entrepreneurs so that failure rates can be reduced and success stories can be created to sustain a steady growth in small-scale projects. As mentioned above, university education has been noted to be a key determinant in fostering new business startups among young people. Although some studies conducted in western countries point out the most important reason why rates of immediate graduate entrepreneurships remain low is that students themselves rarely claim to want to start a business upon graduation due to the heavy debt burden endured during school. The school debt is virtually non-existent in Kuwait as university schooling has been tuition-free at the Kuwait University since its inception in 1967. Furthermore, abundant financial support is available in the forms of loans with attractive grace periods, venture capital financing, and resource allocation.

This paper sheds light on the level of awareness and vigilance among students from both the College of Business Administration and the College of Engineering at Kuwait University in participating in entrepreneurship development programs and establishing small/micro businesses as part of a special business incubator within Kuwait University premises through certain arrangements with sponsorship from the private sector. It is well known that a business incubator makes up an environment that is specially designed to hatch small-scale ventures as it is endowed with several facilities, such as offices, management support, counseling, and knowledge - a situation that allows entrepreneurs to concentrate on carrying out their business plans in order to heave the success rate. The whole project is intended to promote the entrepreneurial spirit among Kuwaiti students so as to consider setting up their own businesses after their graduation from the university. A primary objective of this study is to assess the extent to which educational/training programs, as well as student incubator programs, can lead to increased small business start-ups as an alternative to government hiring. The paper also assesses the attitude among students toward buying from incubated businesses when their products are offered on campus.

\section{LITERATURE REVIEW}

Business incubation, as an idea, gained momentum worldwide in the mid-1980s. Many developed countries sought the importance of supporting entrepreneurship via effectual methods, one of them being business incubation. A business incubator is a system that is created to provide a supportive environment for the incubatees (tenants) through the early stage of setting up their ventures. It is intended to reduce the business risk by both reducing the set-up business cost and providing many supportive crucial services for entrepreneurs. Similarly, the business incubator could sometimes provide an essential link with the business community outside the borders of the country, which leads to more opportunities. The idea of business incubators represents one method of promoting small business ventures in a country. It is routinely set up by universities as part of their role in promoting the entrepreneurial spirit among future generations. All in all, entrepreneurial education and training represents a crucial part of many universities' curricula. Literature is full of articles that document the vital role of university education and training in teaching and inducing students to set up their own business after graduation. 
Bruyat et al. (2000) accentuate that entrepreneurship training and education play a chief role in economic prosperity and facilitates economic developments. Laukkanen (2000) places more weight on the importance of a good and dependable academic curriculum in order to promote healthy perception about small businesses among university students. Gibb (1996) shows how supporting entrepreneurial spirit and training play a major role in propelling a country's economy. McMullan et al. (1987) have stressed the importance of the business incubators as tools in supporting economic growth. They also contend that university education and training, through incubators, is an effective tool to boost the economy. As a result, there have been increasing efforts by academic institutions in devising programs and extensive training seminars that are intended to promote entrepreneurial thinking. As Hill (1988) and Donckels (1991) put it forth, university entrepreneurship training and education is intended to amplify the awareness and the importance of entrepreneurship and business ventures as a better alternative for future careers. In this respect, Interman (1992) specifies two major objectives of any entrepreneurship programs; i.e., entrepreneurship awareness and business creation. Parker (2006) also emphasizes the significance of entrepreneurial education as entrepreneurs draw on their own past experiences and beliefs. Johansson (1991) shows entrepreneurship education to have five main objectives which center around developing skills: 1) know why (i.e. building the required attitudes and motivation for start-up), 2) know how (i.e. attaining technical capabilities necessary to create a business), 3) know who (i.e. promoting vital contacts for developing the business), 4) know when (achieving the sharp intuition to act at the correct moment), and 5) know what (attaining the knowledge base and information for new venture development aspects of entrepreneurial learning).

Solomon et al (1991) show that the university efforts in supporting entrepreneurship are among the first six recommendations to solve several problems of small businesses in the USA. Gibb et al (1996) focused on the meaning of entrepreneurship as opposed to the enterprise creation where the former is more effective and more important than the latter in the sense that entrepreneurship involves developing managerial skills that relate to starting, managing, and developing a business entity. This could be largely enhanced through university business incubation. Rae et al (2001) distinguish between the teachable skills as opposed to the non-teachable skills, and they focus on the more practical elements of entrepreneurship. On a related theme, Jack et al (1998) argue that entrepreneurship is both a science that relates to the functional skills, and an art that relates to the creative aspects of entrepreneurship. Shepherd et al (1997) declare that university entrepreneurship education needs to focus more on the art element. This could be accomplished through creating an environment at which students can practice the skills they learn in business courses, which is accomplished through incubating those students in a real venture at which they work and are rewarded for their work. Cox et al, (2003) compare two groups of students. One group did not receive any entrepreneurship training and the other did. They conclude that those who received the training showed higher self-efficacy than the other group. Similarly, Peterman et al (2003) find that the trained group on entrepreneurship showed a higher perception of desirability after completing the Young Achievement Australia entrepreneurship training program. Lankard (1991) asserts that all academic institutions carry a noble responsibility to help their students in terms of developing their entrepreneurial skills. In his study, Lankard also goes further by proposing required changes in the educational curriculum so as to create entrepreneurial graduates. These changes relate mainly to more practical training in order to produce a targeted number of entrepreneurs. In another study, Louw et al (1997) endeavor to elucidate the entrepreneurial characteristics of the undergraduate students enrolled in South African University and they show that business major students score higher in terms of awareness of the importance of entrepreneurship than all other major fields. Interestingly, and regardless of student gender, they notice that the risk aversion of university students is relatively high in spite of the significance of the risk-taking behavior in entrepreneurship. Confirming the results of the previous study, Drnovsek et al (2001) find that graduate students majoring in entrepreneurship are more likely to start up their own businesses than the MBA students. Ducheneaut (2001) also emphasizes the importance of the practical side of entrepreneurship as he accentuates that universities should detect the potential entrepreneur before training him into special entrepreneurship courses.

The bulk of the literature shows that it is important to have some sort of entrepreneurship education in a university curriculum, but that education cannot by itself create an entrepreneur since only certain aspects of entrepreneurship are teachable. As one puts it forth, "You cannot teach someone to become Bill Gates, but you can provide training to sharpen one's skills". Entrepreneurship education and training is able to equip students with skills needed to qualify those students for success and to enhance their capacity which, in turn, contributes positively to the economy by promoting successful creation of small and medium ventures (Curran et al., 1989). 


\section{Entrepreneurial Spirit in Kuwait}

The government has been playing a vital role in promoting the entrepreneurial spirit among Kuwaitis through its financial resources. The government provided many very attractive financing packages through different governmental agencies and funds. The last was a contract between the government and a private company to invest 15 million $\mathrm{KD}^{1}$ in small projects in participation with young Kuwaitis. The main governmental agencies that provide financing to Kuwaiti entrepreneurs are Kuwait Industrial Bank, Kuwait Small Projects Development Company, National Technological Projects Company, and Industrial Public Authority. In other words, the government has provided enough funding for Kuwaiti entrepreneurs. However, considering the funding obtained from those agencies since their establishments (the latest was the SMEs portfolio in Kuwait industrial bank in 1999), the willingness of Kuwaitis to establish original and potentially successful SMEs is relatively very low.

The reasons for this low willingness to establish SMEs vary. An expert team assembled by the Restructuring Government Program (a governmental body that has programs to encourage young people to either establish a small project or join the private sector) has scrutinized the many problems facing small projects. The team report offered many social problems hindering serious SME startups among Kuwaitis, including stigmatic social status that many members of the society assign to potential entrepreneurs. Furthermore, many people still disdain the idea of establishing a small project, given the attractive government employment with handsome pay which creates more private consumers than employers. The report also refers part of the unwillingness of young people to the unnecessary complex bureaucratic requirements and frustrating rules imposed by the government sector in order to acquire a license for a small business. This bureaucratic cycle could take 4-6 months, a time which exceeds the tolerance of most impatient entrepreneurs. During such a period, the entrepreneur has to pay a relatively huge amount of rent. Besides, there are no regulations or rules that protect the entrepreneur from any type of unfair competition. Furthermore, some of the ideas that originate by those entrepreneurs, when submitted in the form of a feasibility study to a governmental financing agency, are delayed until taken up by corporate or well-connected merchants. The report concludes that the government that has done excellent in providing the financing is, at the same time, destroying its role in promoting the entrepreneurial spirit among young university graduates or easing the legal/procedural difficulties. Elevating the positive spirit requires much more organized efforts.

Beside the governmental role comes the educational role in promoting the entrepreneurial ideas among students. Unfortunately, university education has yet to develop a vital and effective small business program into the university curriculum that could help in creating more awareness and more interest. Nevertheless, the university, through its consulting role, has provided many effective and professional training seminars that play a vital role in helping graduates in establishing their small projects. That role, however, is still minor and not even enough to attract serious entrepreneurs.

This research is conducted to assess the preparedness and willingness of the university students in establishing their own small businesses in a university incubator. This could be a sound indicator to those students willing to set up their own businesses after graduation. The focus of this research is on both business and engineering students since they both take business and project-related courses. The incubator is to be financed by a government-sponsored company that provides financing mainly to small businesses. The research is an analysis of a questionnaire distributed to the students of the engineering and business schools in Kuwait University.. It is believed that many students of the two colleges possess the required skills to start a small business. This belief is based upon the preparation they received in terms of the many project-related courses those students took during their university schooling. At the same time, there is a strong believe that those students have no interest in setting up a small business. This belief is based upon the attractive job opportunity made available by the government. Government jobs in Kuwait are known to be attractive given the minor efforts needed to practice those jobs compared to the high salary paid to government employees.

Hence, this research is supposed to shed light on the issue whether university education in schools of business and engineering creates a motive, appeal, and interest of students in establishing small businesses.

\footnotetext{
${ }^{1}$ Each one $\mathrm{KD}=3.45$ US dollar
} 


\section{RESEARCH HYPOTHESES}

\section{Willingness to Participate in Entrepreneurial SMEs}

The notion of entrepreneurial SMEs in Kuwait is not highly diffused among nationals in society for several reasons. Employment in the government sector has been the preferred route for many nationals, given the attractive pay, relaxed work condition, and high job security. Furthermore, expatriates compose the bulk of employment in the private sector with substantially lower wages and more work hours. It has been expected that after enjoying richness emanating from the oil-era welfare economy, motivation and interest among nationals in working on entrepreneurial SMEs should be less evident. Hence, within a college environment, this trend should be present and, based upon that, it is expected that:

H1a: The majority of students surveyed will show less inclination to work on SME or to become a seller in SMEs

While entrepreneurial SMEs may be one of many sellers making up the supply side of products in the economy, buyers are more numerous in number and the act of buying is much more convenient than selling. In a college environment, buying is more attractive than selling, especially as disposable income is high. Hence, it is anticipated that:

H1b: Most students will be more interested in becoming buyers from Entrepreneurial SMEs compared to becoming sellers in these SMEs.

\section{Gender and Entrepreneurship}

Being a male dominant society, Kuwaiti males will be more likely than females to participate in a college incubated small business. Hofstede (1980) classified Kuwait, as part of the Middle East cluster, as a masculine society where males dominate and their traits are highly diffused and should show more propensity to work in entrepreneurial projects. Consequently, it is expected that:

H2a: More males than females will be interested in selling their products through small businesses.

As demonstrated in $\mathrm{H} 1 \mathrm{~b}$, selling requires investment, time commitment, management, and other logistical considerations, while buying is far less complicated and much easier. Accordingly, it is expected that:

H2b: Males and females will show similar tendencies toward buying products from small businesses owned by other students.

\section{Major and Entrepreneurial Readiness}

Two professional colleges were included in this study: the college of Business Administration and the College of Engineering. While the inception of entrepreneurial projects may be more evident in the engineering school, given the nature of student studies, students at the college of business should be more in touch with market needs focusing more on managing these entrepreneurial projects. Thus, it is expected that:

H3: Business students are more likely to be willing to participate in entrepreneurial projects than do their colleagues in the engineering school.

\section{Academic Performance and Entrepreneurial Spirit}

Students' performance during their studies is an important indication of their dedication, motivation, and intellectual abilities. Nevertheless, the relationship between academic performance and willingness to work on an entrepreneurial project during this study is unclear. It is logical to expect that highly performing students are more likely to participate in such projects to sharpen their skills and to inject realism into their classes. Hence; 
H4: Students with a higher GPA are more likely to be involved in selling in entrepreneurial projects than those with a low GPA.

\section{Academic Year and Entrepreneurial Spirit}

Students mature over the course of their studies. Freshmen are usually perceived as possessing more of fitin attitude than extracurricular activities such as participating in entrepreneurial SMEs. In an affluent society, such as Kuwait, and in a free-of-charge educational system like that at Kuwait University, engagement in such activity may be viewed as unnecessary. Hence, it is expected that:

H5: Students in their early years of study should show less inclination to participate in college entrepreneurial SMEs than in later academic years.

\section{RESULTS}

\section{Willingness to participate in Entrepreneurial SMEs}

In H1a, the primary question is to uncover the extent to which college students are willing to participate in entrepreneurial SMEs in a university setting. We expected weak willingness among college students to participate in SMEs. The expectation was not supported. The results in Table 1 show that $97.6 \%$ of the sample is willing to work on entrepreneurial SMEs and only $2.4 \%$ refused to participate. When we specifically asked students whether they were willing to work between lecture times, almost $96 \%$ indicated that they are willing to participate in working between lecture hours.

Table 1: Willingness to Work on SMEs in College Settings

\begin{tabular}{|c|c|c|c|c|c|}
\hline & & Frequency & Percent & Valid Percent & Cumulative Percent \\
\hline \multicolumn{6}{|c|}{ Willingness to work on SMEs } \\
\hline \multirow[t]{3}{*}{ Valid } & YES & 478 & 97.6 & 97.6 & 97.6 \\
\hline & NO & 12 & 2.4 & 2.4 & 100.0 \\
\hline & Total & 490 & 100.0 & 100.0 & \\
\hline \multicolumn{6}{|c|}{ Willingness to work between hours on SMEs } \\
\hline \multirow[t]{3}{*}{ Valid } & YES & 470 & 95.9 & 97.9 & 97.9 \\
\hline & NO & 10 & 2.0 & 2.1 & 100.0 \\
\hline & Total & 470 & 95.9 & 97.9 & 97.9 \\
\hline
\end{tabular}

In H1b, we expected students to participate as buyers more than sellers. This hypothesis is supported. In Table 2, students showed greater interest in becoming sellers with a mean of six SME projects. When asked if they would buy from Entrepreneurial SMEs, students were quite supportive, showing that they would buy an average of 12 kinds of products.

Table 2: Non-Parametric Analysis of Becoming a Seller and a Buyer in Entrepreneurial SMEs

\begin{tabular}{|c|c|c|c|}
\hline \multicolumn{2}{|c|}{ Parameter } & $\begin{array}{c}\text { As Seller } \\
\text { Total number of projects }\end{array}$ & $\begin{array}{c}\text { As Buyer } \\
\text { Total number of projects }\end{array}$ \\
\hline \multicolumn{2}{|l|}{ Valid N } & 490 & 490 \\
\hline \multicolumn{2}{|l|}{ Mean } & 5.65 & 12.25 \\
\hline \multicolumn{2}{|l|}{ Median } & 6.00 & 12.00 \\
\hline \multicolumn{2}{|l|}{ Mode } & 5 & 12 \\
\hline \multicolumn{2}{|l|}{ Minimum } & 0 & 1 \\
\hline \multicolumn{2}{|l|}{ Maximum } & 17 & 18 \\
\hline \multicolumn{2}{|l|}{ Sum } & 2767 & 6003 \\
\hline \multirow[t]{3}{*}{ Percentiles } & 25 & 4.00 & 10.00 \\
\hline & 50 & 6.00 & 12.00 \\
\hline & 75 & 7.00 & 15.00 \\
\hline
\end{tabular}




\section{Gender and Entrepreneurship}

The analysis shows that $\mathrm{H} 2 \mathrm{a}$ is not supported, but the reverse is true. As is shown in Table 3, one can see that the willingness of female students to work on their own small project is greater than that of male students. That is, if intentions are to be acted upon, female students are more likely to establish their own small business than male students. The mean rank for female students is greater than that of male students. That is, the $\mathrm{MR}_{\mathrm{M}}=167$ while $\mathrm{MR}_{\mathrm{F}}$ $=266$ with $\chi^{2}=15.725$ and $\mathrm{p}<.0001$. This is to say that out of the 167 male students, $130(78 \%)$ students were either equal or below the median, while only $22 \%$ were above the median. As for female students, $40 \%$ were above the median.

The analysis shows that $\mathrm{H} 2 \mathrm{~b}$ is supported. We also tested whether male and female students are willing to work on an entrepreneur project, in general, and also during classes in school. Our analysis of the responses to both offers showed no differences in the responses based on the answers. The significance of the asymptotic 2-sided person chi-square was not significant ( $p>.424$ for working on entrepreneur project and ( $p>.682$ for working between classes).

Table 3: Gender and Degree of Readiness to Become Entrepreneur or to be a Buyer from an Entrepreneur

\begin{tabular}{|c|c|c|c|c|c|}
\hline & Gender & $\mathbf{N}$ & Mean Rank & $\chi^{2}$ & Asymp. Sig. \\
\hline \multirow[t]{3}{*}{ Becoming an entrepreneur } & Male & 167 & 204.05 & \multirow{3}{*}{15.73} & \multirow[t]{3}{*}{.000} \\
\hline & Female & 322 & 266.24 & & \\
\hline & Total & 489 & & & \\
\hline \multirow[t]{3}{*}{ Buying from an entrepreneur } & Male & 167 & 257.88 & \multirow[t]{3}{*}{2.735} & \multirow[t]{3}{*}{.098} \\
\hline & Female & 322 & 238.32 & & \\
\hline & Total & 489 & & & \\
\hline
\end{tabular}

When students were asked if they would buy from a student-owned business, both genders should have similar inclinations and no statistical differences were detected. As shown in Table 4, the mean rank for female students is almost equal to that of the male students $\left(\mathrm{MR}_{\mathrm{M}}=258\right.$ while $\mathrm{MR}_{\mathrm{F}}=238$ with $\chi^{2}=2.7$ and $\left.\mathrm{p}=.098\right)$. Analysis of the median shows that scores above and below the median for male and female students are not that much different, confirming that there is more similarity than differences between male and female students.

Table 4: Median Comparisons for Gender and Willingness to Work with SMEs

\begin{tabular}{llcc}
\hline \multicolumn{2}{c}{ Table 4: Median Comparisons for Gender and Willingness to Work with SMEs } \\
\cline { 2 - 3 } & & \multicolumn{2}{c}{ Male/female } \\
\hline Becoming an entrepreneur & $>$ Median & 37 & Female \\
\cline { 2 - 4 } & <= Median & 130 & 129 \\
\hline \multirow{3}{*}{ Buying from an entrepreneur } & $>$ Median & 92 & 153 \\
\cline { 2 - 3 } & $<=$ Median & 75 & 170 \\
\hline
\end{tabular}

\section{Major and Entrepreneurial Readiness}

In H3, we predicted that business major students will be more involved in entrepreneurial SMEs than nonbusiness students. The analysis shown in Table 5 shows that business and engineering students are significantly different in terms of their willingness to become sellers in an entrepreneurial project $\left(\operatorname{Mean}_{\text {Eng }}=6.54, \operatorname{Mean}_{C B A}=\right.$ $5.07, \mathrm{~F}=36.01, \mathrm{p}<.0001)$ and in terms of being customers to entrepreneurial business $\left(\operatorname{Mean}_{E n g}=11.36, \operatorname{Mean}_{C B A}=\right.$ 12.83, $\mathrm{F}=23.34, \mathrm{p}<.0001)$. As shown in Table 5, engineering students show a higher tendency to become entrepreneurs, but show less inclination to buy from entrepreneurs than business students. 
Table 5: ANOVA Results on College and Degree of Readiness to Become Entrepreneur or to be a Buyer from an Entrepreneur

\begin{tabular}{|c|c|c|c|c|c|c|}
\hline \\
\hline Factor & College & $\mathbf{N}$ & Mean & Mean Ranks & $\mathbf{F}$ & Sig. \\
\hline \multirow{3}{*}{$\begin{array}{l}\text { Willingness to become } \\
\text { a seller }\end{array}$} & CBA & 297 & 5.07 & 241.97 & \multirow{3}{*}{36.012} & \multirow{3}{*}{.000} \\
\hline & Engineering & 193 & 6.54 & 250.92 & & \\
\hline & Total & 490 & 5.65 & - & & \\
\hline \multirow{3}{*}{$\begin{array}{l}\text { Willingness to become } \\
\text { a Buyer }\end{array}$} & $\mathrm{CBA}$ & 297 & 12.83 & 241.18 & \multirow{3}{*}{23.336} & \multirow{3}{*}{.000} \\
\hline & Engineering & 193 & 11.36 & 239.41 & & \\
\hline & Total & 490 & 12.25 & - & & \\
\hline
\end{tabular}

\section{Academic Performance and Entrepreneurial Spirit}

Our prediction in H4 stated that higher GPA students should be more involved in SME projects than lower GPA students. We contrasted the willingness of students to work on entrepreneurial projects between lectures using GPA and major GPA. Results in Table 6 show that those students who don't prefer to work on entrepreneurial SMEs in the college have significantly lower GPA and major GPA.

Table 6: Results of ANOVA on GPA and to Entrepreneur

\begin{tabular}{|c|c|c|c|c|c|c|c|c|}
\hline & & $\mathbf{N}$ & Mean & Source & df & Mean Square & $\mathbf{F}$ & Sig. \\
\hline \multirow[t]{3}{*}{ GPA } & Yes & 426 & 2.95 & Between Groups & 1 & 2.996 & \multirow{3}{*}{10.76} & \multirow{3}{*}{.001} \\
\hline & No & 10 & 2.4 & Within Groups & 434 & .278 & & \\
\hline & Total & 436 & 2.94 & Total & 435 & & & \\
\hline \multirow[t]{3}{*}{ GPA Major } & Yes & 343 & 2.97 & Between Groups & 1 & 3.99 & \multirow{3}{*}{14.52} & \multirow{3}{*}{.000} \\
\hline & No & 9 & 2.30 & Within Groups & 350 & .275 & & \\
\hline & Total & 352 & 2.96 & Total & 351 & & & \\
\hline
\end{tabular}

\section{Academic Year and SMEs}

Results shown in Table 7 lend only partial support to the predictions of H5. While the willingness to work on SMEs is greatest in the fourth year, the statistical test doesn't achieve the desired significance for overall willingness to work on SMEs $\left(\chi^{2}=4.488\right.$ and $\mathrm{p}=.213$ ), while the willingness to work on SMEs between lectures is $\left(\chi^{2}=2.506\right.$ and $\left.\mathrm{p}=.474\right)$.

Table 7: Academic Year and Entrepreneurial Willingness - A Non-Parametric Analysis

\begin{tabular}{|c|c|c|c|c|c|}
\hline Variable & Academic Year & $\mathbf{N}$ & Mean Rank & Chi-Square (df) & $P$. \\
\hline \multirow{5}{*}{ Work on SMEs? } & 1 & 62 & 239.50 & \multirow{5}{*}{$\begin{array}{l}4.488 \\
(3)\end{array}$} & 0.213 \\
\hline & 2 & 75 & 246.03 & & \\
\hline & 3 & 190 & 243.37 & & \\
\hline & 4 & 163 & 250.02 & & \\
\hline & Total & 490 & & & \\
\hline \multirow{5}{*}{$\begin{array}{l}\text { Work between lectures on } \\
\text { SMEs }\end{array}$} & 1 & 62 & 243.24 & \multirow{5}{*}{$\begin{array}{l}2.506 \\
(3)\end{array}$} & 0.474 \\
\hline & 2 & 74 & 238.74 & & \\
\hline & 3 & 188 & 238.05 & & \\
\hline & 4 & 156 & 243.19 & & \\
\hline & Total & 480 & & & \\
\hline \multirow{5}{*}{ Selling in SMEs } & 1 & 62 & 181.21 & \multirow{5}{*}{$\begin{array}{l}19.935 \\
(3)\end{array}$} & 0.0001 \\
\hline & 2 & 75 & 221.77 & & \\
\hline & 3 & 190 & 261.87 & & \\
\hline & 4 & 163 & 261.79 & & \\
\hline & Total & 490 & & & \\
\hline \multirow{5}{*}{ Buying from SMEs } & 1 & 62 & 320.30 & \multirow{5}{*}{$\begin{array}{l}22.997 \\
(3)\end{array}$} & \multirow[t]{5}{*}{.00001} \\
\hline & 2 & 75 & 233.40 & & \\
\hline & 3 & 190 & 246.99 & & \\
\hline & 4 & 163 & 220.88 & & \\
\hline & Total & 490 & & & \\
\hline
\end{tabular}


The willingness to become a seller of many products is the highest in the last two academic years (the mean rank of juniors and seniors $=261$ ) compared to first two years (mean rank first year $=181$, and mean rank second year $=221$ with $\chi^{2}=19.935$ and $p<.00001$ ). Becoming a buyer is the highest among the first year (mean rank first year $=320$; compared to later years $\left.\chi^{2}=22.997, \mathrm{p}<.00001\right)$.

\section{DISCUSSION AND LIMITATIONS}

As we derive from the theory of planned action, the behavior is determined by three components: intention, attitude, and behavior. In order to foster a successful entrepreneurship program, intentions are measured directly in this research. Results show that, contrary to our expectations and to our surprise, willingness to participate in entrepreneurial SMEs is quite high among university students. While these results are encouraging, it is not assumed here that participation in such projects will be high; but, results show a positive outlook.

Another counterintuitive result found in this research is the increased willingness among female students to participate in SMEs than male students, despite the preconceived notion that Kuwait is a male-dominant society and that males are more eager to be business owners than females. The finding that engineering students are more motivated to work on entrepreneurial SMEs than business students traces back to the product inception itself. Our investigation with college professors from engineering leads us to believe that exciting projects are made in engineering classes, yet they lack the business tools to commercialize it; whereas business students may be more effective in commercialization, but not in creating the impetus of entrepreneurial projects. Statistics from MBA enrollment testify to this effect where the majority of MBA enrollments are non-business majors and are especially from engineering majors.

There seems to be a relationship between academic performance and willingness to participate in entrepreneurial SMEs. Highly performing students are more eager to work on SMEs. The overall drive for success among students is related to motivation. In addition, students approaching graduation are more eager to participate in entrepreneurial SMEs, which sends a strong signal to those in charge of promoting entrepreneurship in Kuwait (such as small enterprise development companies) to target this group at the junior and senior stage in order to attract them.

\section{AUTHOR INFORMATION}

Dr. Hassan M. El-Sady, Assistant Professor of Finance at Gulf University for Science and Technology, graduated from the U.S. with Ph.D. in Financial Economics; has several published papers in international journals in the field of country risk analysis, return and risk predictability, stock market development and country creditworthiness, behavioral finance; has three published books in Financial Economics, Financial Management, and Capital Budgeting; supervised more than 10 theses in the finance and investment fields; lectured in several training seminars in the field of finance; and has been a consultant to several organizations.

Turki Alshimmiri, Associate Professor, Finance Dept., College of Business Administration, Kuwait University (finance@alumni.gwu.edu), has lectured in many investment and finance regional training seminars; is a frequent consultant to several private and government organizations in Kuwait; published in several international refereed journals; participated activity in several refereed conferences; refereed several papers in the field of finance and investment; and is an active member in several communities in Kuwait University.

\section{REFERENCES}

1. Bruyat, C. and P. Julien, (2000), "Defining the field of research in entrepreneurship", Journal of Business Venturing 1, V (6): 165-180.

2. Cox, L.W., Mueller, S.L., and S. Moss, (2003), "The Impact of Entrepreneurship Education on Entrepreneurial Self-Efficacy", International Journal of Entrepreneurship Education, V(1): 17-36.

3. Curran, J. and J. Stanworth, (1989), "Education and Training for Enterprise: Some Problems of Classification, Evaluation, Policy and Research", International Small Business Journal, V(7): 112-129. 
4. R. Donckels, (1991), "Education and Entrepreneurship Experience from Secondary and University Education in Belgium", Journal of Small Business and Enterprise 9(1): 35-42.

5. Drnovsek, M, and M. Glas, (2001) Entrepreneurial Intentions of Nascent Entrepreneurs: A Case of Students in Entrepreneurship and MBA Programs, presented at the Conference of Internationalizing Entrepreneurship Education and Training, Krueger Park, South Africa.

6. B. Ducheneaut, (2001), "'Entrepreneurship and higher education from real life context to pedagogical challenge", From Brockhaus, R.H., Hills, G.E., Klandt, H. and Welsch, H.P. (eds), Entrepreneurship Education: A Global View: 128-146.

7. Gibb, (1996), "Entrepreneurship and Small Business Management: Can We Afford to Neglect them in the 21st Century Business School?", British Journal of Management, V(7): 309-321.

8. Y. Gibb and E. Nelson, (1996), "Personal Competences, Training and Assessment: A Challenge for Small Business Trainers", Proceedings of the European Small Business Seminar: 97-107.

9. G. Hills, (1988), "Variations in University Entrepreneurship Education: An Empirical Study of an Evolving Field", Journal of Business Venturing, V(3): 109-122.

10. G. Hofstede, (1980), Culture's Consequences; International Differences in Work-Related Values, Beverly Hills, Calif.: Sage

11. _ (1983), "National cultures in four dimensions: a research-based theory of cultural differences among nations," International Studies of Management and Organization, XIII (1-2):46-74

12. _ (1988), Culture s of consequences. Internationally Differences in Work Related Values. Beverly Hill et al.

13. K. Interman, (1992), "International Management Development Network in Cooperation with the United Nations Development Program (UDP) and the International Labor Office (ILO)", Networking for Entrepreneurship Development, Geneva: International Labor Office.

14. S. Jack and A. Anderson, (1998), "Entrepreneurship Education within the Condition of Entreprenology", Proceedings of the Conference on Enterprise and Learning at Aberdeen.

15. B. Johannisson, (1991), "University Training for Entrepreneurship: A Swedish Approach", Entrepreneurship and Regional Development V(3): 67-82.

16. B. Lankard, (1991), "The Vocational Education/Entrepreneurship Match", published by Eric Clearinghouse Columbus, Ohio.

17. M. Laukkanen, (2000), "Exploring Alternative Approaches in High-Level Entrepreneurship Education: Creating Micro-Mechanism for Endogenous Regional Growth", Entrepreneurship \&Regional Development, V(12): 25-47.

18. L. Louw, A. Plessis, and J. Bosch, (1997), "Entrepreneurial Trades of South African Students: An Exploratory Study", Presented at the Conference Internationalizing Entrepreneurship Education and Training, Monterey Bay, California, USA.

19. W. McMullan and W. Long, (1987), "Entrepreneurship Education in The Nineties", Journal of Business Venturing V(2): 261-275.

20. S. Parker, (2006), "Learning About the Unknown: How Fast Do Entrepreneurs Adjust Their Beliefs? Forthcoming in Journal of Business Venturing.

21. N. Peterman and J. Kennedy, (2003), Enterprise Education: Influencing Students' Perceptions of Entrepreneurship", Entrepreneurship Theory and Practice V(28): 129-144.

22. D. Rae and M. Carswell, (2001), "Towards a Conceptual Understanding of Entrepreneurial Learning", Journal of Small business and Enterprise Development V(8): 150-158.

23. D. Shepherd and E. Douglas (1997), "Is Management Education Developing or Killing the Entrepreneurial Spirit?", Proceedings of the 1997 USASBE Annual National Conference Entrepreneurship: The Engine of Global Economic Development, San Francisco, California.

24. G. Solomon and L. Fernald , (1991), "Trends in Small Business Management and Entrepreneurship Education in the United States", Entrepreneurship Theory and Practice V(15): 25-39. 